\title{
An Examination of Drivers of Financial development: Evidence in West African Countries.
}

\author{
Dr. Adewosi, O. Adegoke ${ }^{1}$,Dr. Manu Donga ${ }^{2}$, Adamu Idi ${ }^{3}$, Buba Abdullahi ${ }^{4}$ \\ ${ }^{1}$ Department of Economics, Modibbo Adama University of Technology, Yola, \\ ${ }^{2}$ Department of Economics, Modibbo Adama University of Technology, Yola, \\ ${ }^{3} \mathrm{PhD}$. Student, Modibbo Adama University of Technology, Yola. \\ ${ }^{4}$ Department of Economics, Gombe State University. \\ Email: adamuidi85@gmail.com
}

\begin{abstract}
Financial development has been considered to play a vital role in promoting rapid growth and development of the developing economies. This paper examined the drivers of financial development in West African Countries. Benin Republic, Burkina Faso, Cape Verde, Ivory Coast, Gambia, Ghana, Guinea, Guinea Bissau, Liberia, Mali, Mauritania, Niger, Nigeria, Senegal, Sierra Leone and Togo over the period of 2000 to 2015, with the proper utilization of panel data estimation technique on the annual country data obtained from World Development Indicators (WDI) 2016 and Worldwide Governance Indicators (WGI) 2016. The results reveals that some important variables such as coefficient of rule of law, political stability, foreign direct investment, government expenditure, inflation and savings positively determined financial development. While, credit to private sector, GDP, interest rate, trade openness, and capital formation were found to negative impact on financial development. The study then recommends amongst others formulation and implementation of fiscal and monetary policies that foster financial development.
\end{abstract}

Keywords: Financial Development, West Africa, Panel Data, Monetary Policy, Fiscal Policy.

\section{Introduction}

A well-developed and functional financial system is viewed to play a vital role in economic growth and development especially in developing countries (IMF, 2014). A wellfunctioning financial system provides the much needed resource for investment that is made available to the investors through various avenues. It help improve the productive capacity of country leading to increase in employment opportunities, alleviate poverty, unemployment, inequality, exchange rate volatility, and unfavorable trade balances (IMF, 2014). 
Pakistan Journal of Humanities and Social Sciences, 6(1), 2018

A developed financial system increases access to capital and consequently to economic growth (Strike, 2015), the allocation of financial resources becomes more efficient as information is given to investors; an organized financial system has the propensity to draw financial resources from off shores with the support of quality legal and regulatory environment. Studies have shown that financial development play a key role in economic growth and development, Falahaty and Hook, (2011) assert that a well-functioning financial system brings about economic growth and development in both developed and developing economies. Financial system play a complementary role of providing financial resources vital for economic growth and development especially in the developing economies that are financially deficient, the extent of openness of developing economies to has a significant impact on the stock market liquidity and hence, financial development. Evidence has shown that stock market openness to the international investors increase volatility in the short run but the volatility tends to subside in the end but growth is sustained (Levine, 1997 and Strike, 2015). African Countries have implemented several economic reforms over the last few decades, with the aim of boosting development of its financial system via the implementation of policies that aimed at boosting the growth and development of financial system that has the capability of propelling the growth and development of their economies rapid investment. In order to achieve this goal, there is a need to identify the determinants of financial development, which will help in the designation of policies and measures to improve financial development especially in Africa.

This paper seek to examine the financial development determinant, based on the theoretical postulation of gross domestic savings, broad money supply, credit to private sector, interest rate, inflation, exchange rate, political stability, rule of law, corruption, trade openness, foreign direct investment and globalization in the context of West African Countries over the period of 2000 to 2015. Firstly, this study employed data from sixteen West African countries. These countries were considered not only because of their size and structure of their financial systems been similar and few country specific studies that have been carried out in them but also because of the role it play in the economic growth and development of Africa.

\section{Conceptual issues}

Financial development has being viewed as the ability to acquire information, enforce contracts, facilitate transactions and create incentives for the emergence of particular type of financial contracts, market, and intermediaries at low cost by the financial sector (Rajan 
\&Zingales, 2008, and Levine, 1999). These can be achieving if financial instruments, markets and intermediaries ameliorate, or eliminate the cost acquiring those services.

It entails availability of ex ante information on new investment, monitoring investment and implementation of corporate governance, savings mobilization and exchange of goods and services, all of which influence savings and investment decisions of individuals, and hence, economic growth.

The financial market development theory postulate that, as long as there is proper regulation of the financial system especially stock market, it will increase the confidence of both foreign and local investors and hence, will be attracted to easily access and invest in the financial system. The theory further assert that, financial development ease access to financial resources with the attraction of foreign capital in to the system and that policies such as low interest rate, low inflation rate, high investment and good corporate governance system provide a bases upon which financial development could achieved (Huang, 2010). The deficiency of domestic capital can hinder the growth and development of not only firms but also the economy at large, therefore, growth and development of a country depends on the development of the financial system especially developing countries including West African sub region.

\section{Empirical Review}

The seminal research by Schumpeter (2011) sparked a voluminous amount of studies in the area of finance-growth nexus. Early studies by Mackinnon (1973), Show (1973), Levine (1997) and of recent, Cemoglu, Johnson \& Robinson (2001), Levine (2005), Rajan \& Zingales (2008), among others, all in their separate papers posit that a developed financial system help the savings and investment decisions of individuals, firms, government policies and legislations.

In a separate study, Mohamed \& Nahed (2015) investigated the impacts of financial development on economic growth in North African countries over a period of 1980 to 2012, using generalized method of moment (GMM), found that democracy, economic freedom, trade openness, were significant determinants of economic growth over the study period. Zhang, et. al, (2012) investigated the determinants of financial development in 286 Chinese cities, over the period of 2001 to 2006, using autoregressive distributed lag model (ARDL), found that, credit to public sector, rule of law and democracy significantly determined financial development. In addition, Alen et.al. (2014) investigated the determinants of financial development in Africa, using OLS technique, found that, population, population 
density, per capita income, inflation, natural resources, manufacturing, capacity utilization and economic growth significantly determined financial development in Africa. similarly, Kablan, (2010) investigated the impact of financial development on bank efficiency in Sub Saharan Africa over a period of 1980 to 2002, using GMM technique, found that regulatory and credit environment significantly determined bank efficiency while political and economic environment were in significant over the study period.

Aluko and Ajayi (2018) investigated the determinants of banking sector development in Sub- Saharan Africa, using system GMM, repot that population density, simultaneous trade openness, and influence the level of banking development. They also report that, banking laws, inflation and religion influence the level of banking efficiency while trade openness, income level, and ethnic diversity affect banking development.

Elkhuizen, Hermes, Jacobs and Meesters (2018) study financial development, liberalization and social capital in 82 countries using random and fixed effect model, report that, financial liberalization and social capital influence financial development in both develop, emerging and developing countries.

Tayssir and Feryel (2018) study the nexus between central bank and financial development in 89 countries over the period of 1980 to 2010, report that central bank, all over influence level of financial development.

Cherf and Dreger (2016) investigated the institutional determinants of financial development in MENA countries, using random and fixed effect model report that institutional conditions are main determinants of financial development. They also report that corruption play a key role the banking sector and rule of law in the stock market, and generally, income per capita, and trade inflation, trade openness play a key role in all aspect of financial development.

Strike (2015) investigated the determinants of financial development in Southern African countries, over a period of 1996 to 2010. Using GMM technique, found that, public sector credit, income per capita, GDP, gross fixed capital formation, financial openness, interest rate, significantly determined financial development while savings and government debt where found to have negative impact on financial development over the study period.

In a separate studies, Shaheen, et. al. (2011), Rachdi \& Mensi, (2012), Takyi \& Obeng (2013), investigated the determinants of financial development, using GMM technique, found that, strong institutions, adequate implementation of financial reforms, savings, interest rate, financial openness, conducive macroeconomic policies, remittances, 
liquidity, level of income, cultural differences, geographical characteristics and low inflation collectively determined financial development.

Based on the above review, there is a possibility of West African countries to improve by improving the level of financial development which could be achieve through a solid understanding of the drivers of financial development of West African countries, given capability of financial development to propelled rapid growth and development in those countries being capital deficient. Findings from the review varied depending on the country or regional specific factors, and the differences in the level of income and other variables used in analysis.

\section{Data and Methodology}

The study uses panel data estimations which have been supported by Strike (2015) and Hassan et.al, (2010). Panel data was employed because it provided more points of data, increases the efficiency of estimators, and reduced the problems of multi-collinearity. It also increases the degree of freedom in the estimations and helps in controlling the problem caused by country and time specific effects. The study employs annual country data for a period of 2000 to 2015, which were obtained from World development indicators (WDI) 2016 and Worldwide Governance indicators (WGI) 2016.

The model can be specified as follows:

$$
Y_{i t}=\beta 0+\alpha \sum Z_{i t}+\pi_{i t}
$$

Where $\mathrm{Y}$ is the dependent variable in country $i$, and $\mathrm{Z}$ is the vector of country specific regressors, $\beta 0$ is the intercept, $\alpha$ is the slope parameter. ' $i$ ' is the unobserved country specific effects. The $\pi$ is the usual white noise error term.

Because of restrictive nature of the common constant by pooling model, that did not take into account the individual specific effect, random and fixed effects method of estimation were employed. In the random effect model assume the constant to be random, so, random model allows different constant for each section to be random.

The random model can be started as follows:

$$
Y_{i t}=\beta Y_{i}+\alpha Z_{i t}+v_{i}+\pi_{i t}
$$

To test whether the pool or random model is appropriate, the Langrage Multiplier test was employed.

$$
\text { The } \mathrm{H}_{0: \delta}{ }^{2}=0
$$


If the calculated chi-square value is greater than the tabulated value we reject the null hypothesis and conclude that random effect model is appropriate. Having established the presence of individual specific effect in the model, this necessitated the need for fixed effect model. The fixed effect model assume that the individual specific effects are fixed across entities, the cross sectional effect is captured by the dummy Di which represent the countries, the fixed effect model can be stated as:

$$
Y_{i t}=\beta Y_{i}+\alpha Z_{i t}+\sum D i+\pi_{i t}
$$

The fixed effect assumed that each country differs in its intercept term whereas random effect model assumed that each country differs in error term. Hausman test (1978), was employed to choose which of the model is appropriate between random and fixed effect model. The test assume the null hypothesis of no correlation, that is, both Ordinary Least Squares (OLS) and Generalized Lease Squares (GLS) are consistent and OLS is inefficient, while alternative hypothesis is that OLS is consistent but GLS is not. The Hausman test model can be started as follows:

$H=\left(\beta^{F E}-\beta^{R E}\right)\left[\left(\operatorname{var}\left(\beta^{F E}\right)-\operatorname{var}\left(\beta^{R E}\right)\right]^{-1}\left(\beta^{F E}-\beta^{R E}\right) \rightarrow X^{2}(k)\right.$

If the of H-statistic is less than 0.05 , we reject the null hypothesis and conclude that fixed effect model is appropriate.

Table 1: Pooled, Random and Fixed Effects Model estimation result

\begin{tabular}{|c|c|c|c|}
\hline \multirow{2}{*}{ Variables } & Pooled Model & $\begin{array}{c}\text { Random Effect } \\
\text { Model }\end{array}$ & $\begin{array}{c}\text { Fixed Effect } \\
\text { Model }\end{array}$ \\
\hline \multirow{2}{*}{ Rulelaw } & 0.048 & 0.048 & 0.027 \\
\cline { 2 - 4 } & $(4.97)^{* *}$ & $(4.97)^{* *}$ & $(3.88)^{* *}$ \\
\hline \multirow{2}{*}{ Polistab } & 0.004 & 0.004 & 0.000 \\
\hline \multirow{2}{*}{ Creditpriv } & $(0.75)$ & $(0.75)$ & $(0.02)$ \\
\cline { 2 - 4 } & -0.005 & -0.005 & 0.008 \\
\hline \multirow{2}{*}{ Fdi } & $(2.21)^{*}$ & $(2.21)^{*}$ & $(1.92)$ \\
\cline { 2 - 4 } & -0.013 & -0.013 & -0.038 \\
\hline \multirow{2}{*}{ Gdp } & $(0.73)$ & $(0.73)$ & $(2.86)^{* *}$ \\
\cline { 2 - 4 } & -0.003 & -0.003 & -0.011 \\
\hline \multirow{2}{*}{ Goexp } & $(0.92)$ & $(0.92)$ & $(1.66)$ \\
\cline { 2 - 4 } & 0.021 & 0.021 & 0.024 \\
\hline \multirow{2}{*}{ Inflation } & $(4.21)^{* *}$ & $(4.21)^{* *}$ & 0.012 \\
\cline { 2 - 4 } & 0.004 & 0.004 & $(1.26)$ \\
\hline \multirow{2}{*}{ Interest } & $(0.31)$ & $(0.31)$ & -0.003 \\
\cline { 2 - 4 } & -0.005 & -0.005 & $(0.61)$ \\
\hline \multirow{2}{*}{ Tradopen } & $(0.94)$ & $(0.94)$ & $(1.55)$ \\
\hline \multirow{2}{*}{ Savings } & -0.019 & -0.019 & 0.015 \\
\hline \multirow{2}{*}{} & $(2.40)^{*}$ & $(2.40)^{*}$ & \\
\hline
\end{tabular}




\begin{tabular}{|c|c|c|c|}
\hline & $(2.20)^{*}$ & $(2.20)^{*}$ & $(1.54)$ \\
\hline \multirow{2}{*}{ Capforma } & 0.021 & 0.021 & 0.036 \\
\cline { 2 - 4 } Constant & $(2.38)^{*}$ & $(2.38)^{*}$ & $(3.08)^{* *}$ \\
\hline $\boldsymbol{R}^{2}$ & -1.614 & -1.614 & -2.350 \\
\hline $\begin{array}{c}\text { Number of } \\
\text { Observations } \\
\text { Hausman test }\end{array}$ & $(4.39)^{* *}$ & $(4.39)^{* *}$ & $(3.10)^{* *}$ \\
\hline LM-test & 0.86 & & 0.72 \\
\hline
\end{tabular}

Source : Authors' Computation using Stata 14

Note: $* * *, * * \& *$ indicate significance at $1,5 \& 10$ percent LM-test to choose between pooled OLS and fixed effects models, Hausman test to choose between Fixed and Random Effects Models and the Standard Errors are in Parenthesis

The choice is first made between the pooled OLS and Random Effects (RE) as an appropriate model using LM-test and the probability value of the LM-test favors random effect model as appropriate. We also estimate the model with fixed affects (RE) approach, and use the Hausman test to choose the appropriate model, between random and fixed effect, and fixed effect model was found to be appropriate. However, by way of analysis, the coefficient of rule of law was found to significantly influence financial development at a conventional 5 percent level. The simple explanation is that, the effectiveness of the regulatory institutions and adherence to the rule of law promote the development of a robust financial system capable of triggering rapid growth and development in Africa. This result is in tandem with study of Kablan (2010). Political stability conforms to the appriori expectation but statistically insignificant determinants of financial developments. This is not a surprise as many countries in the continent are battling with one form of crisis or the other that has seriously affected the level of financial development. Most importantly is that political stability coefficient conveys insignificant result though conform to the appriori expectation across all estimators. Credit to private sector, has a negative and significant impact on financial development at 5 percent level. This is not a surprise, as most of the credit in Africa does not go to productive activities, people mostly borrow to finance unproductive activities like wedding, burial and other activities which seriously affect the level of financial development in Africa although there is no enough literature that postulate this. Foreign Direct Investment (FDI), a measure of financial openness, did not conform to the appriori expectation as well as been not statistically in significance. This contradicts studies by Kablan 
Pakistan Journal of Humanities and Social Sciences, 6(1), 2018

(2010), Zhang et. al (2012) and Alen (2014). This is simply because of the fact that foreign investors are reluctant to reinvest their profit in host countries financial market especially the stock market that has the propensity to develop the financial system. GDP, a measure of economic growth, did not conform to the economic theory and as well as insignificant at all conventional levels, this also contradict the studies like Zhang et, al (2012) and Alen (2014).

The simple explanation of this is that most of the people are poverty ridden in Africa, due to low income and hence people embark on working in exchange for food (trade by barter). Government expenditure, a measure of government size conform to the economic theory and statistically significant at a conventional 5\% level. This corroborates with Kablan (2010) result. In Africa, due to low level of income government tend to intervene in the economy through massive expenditure and hence, significantly determined financial development. Inflation, a measure of economic stability, conforms to appriori expectation but statistically in significant. This is in tandem with Kablan (2010). This is due to the low level of productivity in Africa as any attempt improves the level of financial development led to increase in price level and hence, induce the level of productivity. Interest rate, though conform to the economic theory but statistically insignificant, the simple explanation of this is that, in Africa the rate of interest is mostly fixed by the government, and it is not flexible which seriously affect the investment capacity of the economy in form of crowding out effects and hence, financial development. Trade openness, a measure of openness of the economy, did not conform to appriori expectation though statistically significant at 10 percent level. This simply means that in Africa where financial corruption has become order of the day and most of the fund stolen is taken outside the continent instead of investing in the continent to provide employment opportunities to the teeming unemployed and financial development through increase in savings. Savings though positive but not statistically significant at any conventional level, this simply justifies the fact that savings is very low in developing countries with Africa inclusive, Capital formation, a measure of investment, conform to the appriori expectation and significant at 10 percent. The simply explanation is that investment play a vital role in financial development and Africa need to put in more effect to increase the rate of investment in the continent.

\section{Conclusion and policy recommendations}

To explore the determinants of financial development in West African Countries over the period of 2000 to 2015 , the important variables adjudge to be crucial determinants of financial development in Africa were explore using panel data technique. Rule of law, 
political stability, government expenditure, inflation, savings and capital formation have positive impact on financial development while private sector credit, FDI, GDP, rate of interest and openness to trade have negative impact on financial development. It is therefore worth noting that rule of law, political stability, government expenditure, inflation, savings and capital formation increase financial development, and credit to private sector, foreign direct investment, and GDP, interest rate and trade openness drags financial development in Africa.

On the bases of the empirical outcomes, it is recommended therefore that credit should be given to those who will use it for productive investment, this could be achieved through monitoring the project which the credits is been provided for. The continent should also put in place a policy that encourage reinvestment of profit especially by the foreign investors in the continent, this could be achieve through giving tax incentives on profit to be reinvested and heavy tax on the repatriated profits in addition to putting in place measures that discourage capital flight and looting. In addition, interest rate should be flexible, it could be achieve through minimal or even absence of government intervention in the interest rate determination all these will help in financial development in West Africa battling with capital deficit. Finally, West African Countries should put in place appropriate monetary and fiscal policy that promotes rapid growth and development of the financial system. 
Table 2:

\begin{tabular}{|c|c|c|c|}
\hline Variable & Definition & Source & Expected sign \\
\hline $\begin{array}{l}\text { Liquidity Liability } \\
\text { and commercial bank } \\
\text { branches proxy of } \\
\text { financial } \\
\text { development }\end{array}$ & $\begin{array}{l}\text { Broad money supply (M2) as \% of } \\
\text { GDP and the bank branches }\end{array}$ & WDI & $\begin{array}{l}\text { Dependent } \\
\text { variable }\end{array}$ \\
\hline Savings & Total savings as \% of GDP & WDI & Positive \\
\hline Economic Growth & Annual \% growth rate of GDP & WDI & Positive \\
\hline Trade Openness & Total trade $\%$ of GDP & WDI & Positive \\
\hline Financial Openness & $\begin{array}{l}\text { Foreign Direct Investment (FDI) \% } \\
\text { of GDP }\end{array}$ & WDI & Positive \\
\hline $\begin{array}{l}\text { Domestic credit by } \\
\text { banks. }\end{array}$ & $\begin{array}{l}\text { Domestic credit to all sectors } \% \text { of } \\
\text { GDP }\end{array}$ & WGI & Positive \\
\hline Rule of Law & $\begin{array}{l}\text { Strength, impartiality and legal } \\
\text { system as well its observance. } \\
\text { Measured from 1(strong law and } \\
\text { order) to } 0 \text { (weak law and order). }\end{array}$ & WGI & positive \\
\hline Political Stability & $\begin{array}{l}\text { A measure of government stability, } \\
\text { level of internal and external } \\
\text { conflicts and ethnic tensions. } \\
\text { Measured from values ranging from } \\
0 \text { (high level of political instability) } \\
\text { to } 1 \text { (low level of political } \\
\text { instability) }\end{array}$ & WGI & positive \\
\hline Inflation & $\begin{array}{l}\text { Consumer price index a measure of } \\
\text { stability }\end{array}$ & WDI & Negative \\
\hline Capital Formation & $\begin{array}{c}\text { Capital formation as \% of GDP a } \\
\text { measure of investment }\end{array}$ & WDI & Positive \\
\hline $\begin{array}{l}\text { Government } \\
\text { Expenditure }\end{array}$ & $\begin{array}{c}\text { Total government expenditure as \% } \\
\text { of GD, a measure of government } \\
\text { size }\end{array}$ & WDI & Positive \\
\hline
\end{tabular}

Source: world Development Indicators (2016) and Worldwide Governance Indicators (WGI) 2016. 


\section{References}

Alen, F. (2004) The African Financial Development and Financial Inclusion Gaps, Policy Research Making Paper7019.

Aluko,O \& Ajayi, A (2018) Determinants of Banking Sector Developments: Evidence from Sub-Saharan African Countries, Borsa Instanbul Review, Vol.18(2), pp 122-139.

Cemoglu, A, Johnson, B, \& Robinson, A (2001) Does Financial Sector Growth Crowd Real Economic Growth? BIS Working Paper, Basel Bank of International Settlement.

Cherif, M and Dreger, C (2016) Institutional Determinants of Financial Development in MENA countries, Review of Development Economics, Vol.20 (3), pp 670-680.

Elkhuizen, L \& Hermes, N, Jacobs, J \& Meesters, A (2018) Financial Development, Financial Liberalization and Social Capital, Journal of Applied Economics, Vol50(11).

Falahaty, M \& Hook, L. S. (2015) The Determinants of Financial Development: the New Evidence from Middle East and North Africa region, Faculty of Economics, University ofKebansaan, Malaysia, unpublished paper.

Hausman, J. A.(1978) Specification test in Econometrics, Economerica, Vol. 46(6), pp12511271.

Huang, Y. (2010) Determinants of Financial Development, Palgrave Macmillan, UK.

IMF (2014) Advancing Financial Development in West Africa, in Regional Economic outlook, West Africa, Washington, October, 2014.

Kablan, A. (2010) The Impact of Financial Development on Banking Efficiency: Evidence from Sub-Saharan Africa, Journal of Banking and Finance, Vol.4(6), pp39-43.

Law, S. (2011) Capital Flows, Trade Openness and Financial Development in Developing Countries, International Economic Journal, and Vol.23 (3). Pp: 409-426.

Levine, R. (1973) Stock Market, Economic Development and Capital control Liberalization, Investment Company Institute Perspectives, Vol.3(3).

Levine, R. (1999) Financial Development and Economic Growth, Views and Agenda, Journal of Economic Literature. Vol.35 (2), pp: 688-726.

Levine, R. (2005) Finance and Growth: In Hand Book of Economic Growth, edited by Aghion, P. and Durlauf, A; Amsterdam, Elsevier.

Mackinnon, R. I. (1973) Money and Capital in Economic Development, Washington DC: Brookings Institutions. 
Mohamed, C. \& Nahed, K. (2015). The Determinants of Financial Development: Empirical Evidence from Egypt; The Macro theme Review, A Multidisciplinary Journal of Global MacroTrends, Vol.4 (3); pp: 69-87.

Rachdi , H \& Mensi, S (2012) Does Institutional Quality Matters for Financial Development and Economic Growth Nexus? Another look at the Evidence from MENA countries, Economic Research Forum, Working Paper 705.

Rajan, R. S. \& Zingales C. (2008). The Great Reversals: The Politics of Financial Development in the twentieth century, Journal of Development Studies, 2(4), 23-45.

Schumpeter, J. A. (2011) The Entrepreneur, Stanford University Press

Shaheen, S. (2011) Financial Development, International Trade and Economic Growth: Empirical Evidence from Pakistan, Romanian Journal of Fiscal Policy, 2(2), 11- 19.

Show, E. S. (1973) Financial Deepening in Economic Development, New York, New York University Press.

Strike, M (2015) Determinant of Financial Development in Southern African Development Community (SADC): Do Institution Matters?

Tayssir, O. \& Feryel, O. (2018) Does Central Banking promote Financial Development? Borsa Instanbul Review, 18(1), 52-75.

Takyi, P. O. \& Obeng, C. K. (2013) Determinants of Financial Development in Ghana, International Journal of Development and Sustainability, 2 (4), 2324-2336.

World Bank (2016) World Bank Development Indicators. http://www.data.worldbank.org.

World Governance Indicators (2016) World Wide Governance Indicators. http://www.worldwidegovernanceindicators.org.

Zhang, et al, (2012) Exploring the Determinants of Financial Development Panel Data, Evidence from Developed and Developing countries, Journal of Finance and Economics, 2(5), 166-172. 